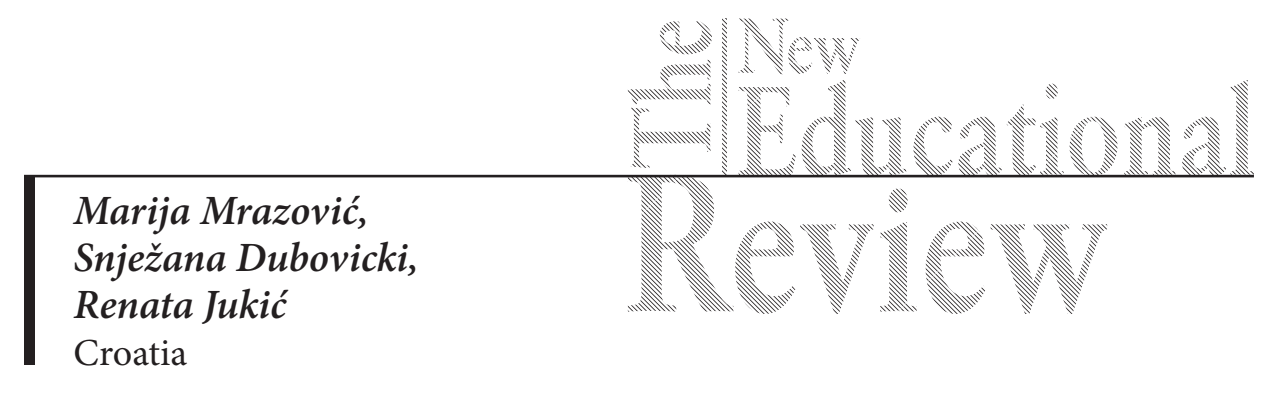

\title{
Students' Satisfaction with Communication in University Teaching. Comparison of Private and State Colleges. Croatian Experience
}

DOI: $10.15804 /$ tner.2015.42.4.07

\begin{abstract}
Communication in university teaching has been experiencing years of reform led by modern media and technologies. This paper examines (by triangulation) satisfaction with university communication in students of private and state universities, which consider communication as one of the most important competence frameworks. The survey examined students' perceptions $(\mathrm{N}=267)$ on the characteristics, methods, frequency, and quality of communication in the learning process, which is our primary research question. What was also researched was the existence of differences in students' attitudes towards private and state universities. Results show that the students of private universities, compared to the students of state universities, are more satisfied with communication.
\end{abstract}

Keywords: state and private universities, communication, university teaching, students' satisfaction

\section{Introduction}

Talking about communication, we know that it is almost impossible to find a uniform definition encompassing all that it implies. Different authors define this phenomenon differently. In defining communication, Čudina-Obradović \& Težak (1995) emphasize the importance of social skills that are closely connected. The definitions of communication and the communication process, multiply deter- 
mined, depend on the point of view, knowledge and attitudes of those who study it. Communication is defined as a process of direct or indirect exchange of meaning; mutual giving and receiving messages through different characters. Communication is, as opposed to information, a two-way process, and feedback is its integral part. Many theories that explain the essence of the communication process have been developed in the last 60 years. According to Shannon-Weaver's (SW) communication model (1948), when sending a message from one person to another, the person sending the message must encrypt their thoughts and feelings, find the words, verbally and non-verbally code their meaning. Communication is, therefore, a two-way process of achieving mutual understanding, in which the participants not only exchange (coding-decoding) information, news, ideas or feelings, but also create and share meaning. Considering that, contemporary communication theorists resent the SW model's linearity and disregard for constant feedback and they try to complete it with complex concepts that include feedback (Duff, 2003). This paper emphasizes the importance of communication in university teaching, which is considered as a two-way process in which all participants are equal and participate actively by exchanging opinions, experiences and ideas, thereby enhancing the learning process.

\section{Teaching as a communication process}

Teaching is an organized institutional and non-institutional creative interaction, a partnership process of acquiring knowledge, abilities, skills and habits that prepare students for lifelong learning. A course objective is to create a critical, emancipated, creative and humane, multicultural personality, open to change in itself and society. Bratanić (2002) says that teaching communication not only has a purpose of information, but also is supposed to encourage thinking and creativity of all, enriching their spirit and developing their personality.

Wrench, Richmond \& Goriian $(2009$, p. 4) define teaching communication as a "process in which the teacher establishes an efficient and emotional communication link with students, so that students can achieve optimum performance in the learning environment." We can conclude that teaching, especially at university, is a communication process in which the professor ${ }^{1}$ and the student ${ }^{2}$ work as partners and

1 The term "professor" refers to persons of both sexes (in a variety of professions) who teach at universities.

2 The term "student" refers to persons of both sexes involved in teaching performed at universities. 
engage in achieving objectives and tasks of teaching, curriculum content is the work subject, joint activities for development and progress. In university teaching the student should not be a passive observer, an object, but should continuously, actively participate in communication (in all forms). Students' passivity, as well as poor communication with teachers, can lead to helplessness, withdrawal, a sense of inadequacy or defeat. Although teaching is a special form of the communication process, there are few studies that systematically research communication from the pedagogical aspect (Duff, 2003).

Recently, various authors (Sekulić-Majurec, 2007; Bognar \& Dubovicki, 2012; Dubovicki \& Banjari, 2014) emphasized the new, changed role of the university professor as compared with the time in which university professors generally gave lectures, whose main role was to transfer knowledge. This paper understands communication as the main driver and motivator of student learning activities.

\section{Communication crisis or contemporary communication era}

Recent research (Pirani \& Sheehan, 2009; Salloum, 2011) warns of communication crisis, at least the sort that has existed so far (face to face), but embraces the flood of communication that takes place with the use of modern technology (Čaldarović \& Šarinić, 2008) that has not missed the teaching process. Exploring modern communication means, they emphasize the possibility of mobile communications (Vaughan \& Lawrence, 2013; Fojtik, 2014), which should be much more present in university teaching.

Research results (Vaughan \& Lawrence, 2013) show that study participants indicated that mobile devices could be useful for supporting future professional responsibilities (career-long learning, collaboration) and facilitating student learning but less effective for planning, assessment, and managing the classroom environment. Salloum (2011) states that that respondents feel comfortable when using CMC tools, e-mail, forums, web conferencing, and chats and consider them useful tools in developing social skills, and maintaining communication. Participants who, in addition to Web conferencing, use forums perceive higher learning and cognitive abilities. Research shows that forum discussions are very successful in promoting learning and teaching (students can teach each other). Following these changes, teaching communication should get a new, improved version in which we can draw the best that will increase the quality of teaching communication. 


\section{Research Methodology}

\section{General Research Background}

Our research methodology included three major components: a literature review, quantitative questionnaire research and web-based quantitative interviews. For the above reasons, the empirical part of the paper is divided into three parts. During the research, attention was paid to ethics.

The study aim was to determine students' satisfaction with communication in the teaching process with the help of features, modes, frequency of communication and quality, but also examination of the existence of differences with respect to these variables between private and state universities. The following variables were defined: the independent variable refers to the type of schools (private/public), the dependent variables refer to respondents' socio-demographic characteristics, satisfaction with communication, teacher characteristics, quality and competence of teachers associated with communication, style of communication between teachers, interpersonal communication features, teaching communication features and communication frequency.

Considering the research goal, the following hypotheses were formulated:

H1. The content and learning outcomes of implementing plans of private colleges show a greater emphasis on communicative competence in relation to state colleges.

H2. Private college students are more satisfied with teaching communication than state college students.

H3. Private college students report greater presence of the characteristics of teaching communication in comparison with state college students.

\section{Research Sample, Instrument and Procedures}

The study was carried out on two occasions. During 2013, pedagogical documentation related to the comparison of public and private universities was explored, and the same year research was conducted with the use of a quantitative questionnaire, in which $\mathrm{N}=227$ subjects participated, from undergraduate and graduate studies at the Faculty of Philosophy, Teacher Education, Faculty of Economics in Osijek, the Department of Physics in Osijek, VERN in Zagreb, ZSEM (Zagreb School of Economics and Management) in Zagreb and at ACMT in Dubrovnik (American College of Management and Technology). The snowball method was 
used for collecting data. Descriptive statistics were used and $t$ - test for independent samples. The data were processed with the use of statistical software for computer data processing (SPSS).

Data was gathered by student questionnaire, adopted from Katz \& McClellan (1999) and transformed for the purposes of this study $(\alpha=0.80)$. It contains closed questions and a Likert-scale estimate of 5 degrees of quality and satisfaction ( 1 - completely unsatisfied, 5 - completely satisfied; - 1 not observed, 5 - always present) and frequency (1- never, 5 - always). The questionnaire consists of two parts. The first part includes five questions concerning sociodemographic characteristics in which respondents provide specific information: age, sex, college, year of study and number of courses per semester. The second part consists of questions concerning teaching communication, satisfaction with communication with teachers and certain forms of communication, qualities and competencies of professors, teachers' styles and characteristics and characteristics of interpersonal communication.

The second part was conducted in 2014, in which the students (of the same, above-mentioned faculty, $\mathrm{N}=40$ ), via an online interview, expressed their views on satisfaction with communication in university teaching.

\section{Data Analysis and Research Results}

\section{Literature review}

In this part of the research, we studied pedagogical documentation related to implementing plans and programs of selected state (Faculty of Philosophy in Osijek) and private (VERN in Zagreb) universities for the purpose of detecting communicative competences visible in content and learning outcomes. Because of the number of different majors in both colleges, the contents and outcomes of the majors which emphasize the communicative competence were explored. At the Faculty of Philosophy in Osijek: pedagogy undergraduate and graduate study, and at VERN in Zagreb: business communication management graduate study. Because of the uniformity of researched documents, the authors investigated Pedagogy graduate study to better collate with Business communication management graduate study (Table 1).

Although the course number is not the same, for comparison we can see the percentages according to which it is seen that in the content and learning outcomes the private universities have a greater representation of communicative 
Table 1. Representation of communicative competence in learning outcomes.

\begin{tabular}{|c|c|c|}
\hline \multirow[b]{2}{*}{ Type of study } & \multicolumn{2}{|c|}{ Learning content and outcomes } \\
\hline & $\begin{array}{l}\text { Total course } \\
\text { number }\end{array}$ & $\begin{array}{l}\text { No. of courses with noted com- } \\
\text { munication competencies }\end{array}$ \\
\hline Pedagogy graduate study & 13 & $6(46 \%)$ \\
\hline $\begin{array}{l}\text { Business communication management } \\
\text { graduate study }\end{array}$ & 23 & $15(65 \%)$ \\
\hline
\end{tabular}

competence than the state universities. These survey results confirm H1: Content and learning outcomes of implementing plans of private colleges show a greater emphasis on communicative competence in relation to state colleges.

\section{Quantitative questionnaire research}

The study comprised students of undergraduate and graduate studies at the Faculty of Philosophy, Teacher Education, Faculty of Economics in Osijek, Department of Physics in Osijek, VERN in Zagreb, ZSEM (Zagreb School of Economics and Management) in Zagreb and at ACMT in Dubrovnik (American College of Management and Technology), involving a total of $\mathrm{N}=227$. Basic statistical indicators more closely explain the sample structure. The total number was $\mathrm{N}=227$ $(\mathrm{M}=50, \mathrm{~F}=177, \mathrm{M}=23.73, \mathrm{SD}=4.122)$. There were 62 students from the Faculty of Philosophy in Osijek, 26 students from Teacher Education in Osijek, 11 students from the Economics Faculty in Osijek, 13 students from the Department of Physics in Osijek, 46 students from VERN in Zagreb, 65 students from ZSEM in Zagreb and 4 students from ACMT in Dubrovnik. For the purposes of further analysis, the students of the Faculty of Philosophy, Teacher Education, Faculty of Economics and Department of Physics will be classified as "state colleges" $(\mathrm{N}=112)$, while the students of VERN, ZSEM and ACMT will be classified as "private colleges" $(\mathrm{N}=115)$.

Alongside the statistical indicators of the test sample, differences between the students of private and state universities in various aspects of satisfaction with teaching communication were considered. T-tests results show that the private college students are more satisfied with communication with teachers $(t=6.578$, $\mathrm{df}=225, \mathrm{p}=0.000$ ). In addition to student general satisfaction with communication, we evaluated some aspects of communication satisfaction to further check their general satisfaction: the students' satisfaction with efficiency, affordability and response time. 
Results show the existence of differences between the private and state college students regarding their satisfaction with communication effectiveness. Overall ratings are higher with the private college students as compared with the assessment of the state college students $(t=4.094, \mathrm{df}=225, \mathrm{p}=0.000)$. Looking at specific communication forms, satisfaction with consultation efficiency before/after class $(\mathrm{t}=4.215, \mathrm{df}=225, \mathrm{p}=0.000)$ and during teaching hours $(\mathrm{t}=5.886, \mathrm{df}=225, \mathrm{p}=0.000)$ rated significantly higher scores by the private college students. In addition to communication efficiency, we explored another dimension, i.e., accessibility. By analyzing satisfaction with communication accessibility between the private and state college students, a difference in overall satisfaction and in some forms of communication was statistically confirmed. The private college students reported greater satisfaction with accessibility of communication before/after class ( $\mathrm{t}=4.054$, $\mathrm{df}=225, \mathrm{p}=0.000)$ and during teaching hours $(\mathrm{t}=5.522, \mathrm{df}=225, \mathrm{p}=0.000)$ than the state college students. The next component is related to response time of processors (using different communication forms).

T-tests, regarding the results of satisfaction with time, show statistically significant differences between the private and state colleges. The private college students express greater satisfaction with the response time of consultation before/after class $(\mathrm{t}=4.584, \mathrm{df}=225, \mathrm{p}=0.000)$ and consultation during teaching hours $(\mathrm{t}=6.329$, $\mathrm{df}=225, \mathrm{p}=0.000$ ). These findings suggest a necessity of changing the way and speed of communication in the state colleges. Results show that the private college students showed greater satisfaction with class communication than the state college students, confirming $\mathrm{H} 2$ Private college students are more satisfied with teaching communication than state college students.

For future research on class communication, we examined the students' views on its current "picture" (current state) regarding: simplicity, clarity, brevity (length) and interest (Table 2).

Table 2. Students' perceptions of the characteristics of class communication

\begin{tabular}{lllllllll}
\hline $\begin{array}{c}\text { Class communi- } \\
\text { cation (CC) }\end{array}$ & Type of college & N & M & SD & t & df & p \\
\hline general attitude & private & 115 & 3.85 & 0.74 & & & \\
\cline { 2 - 5 } & state & 112 & 3.26 & 0.66 & 6.35 & 225 & .000 \\
\hline CC is simple & private & 115 & 3.89 & 1.06 & & & \\
\cline { 2 - 5 } & state & 112 & 3.24 & 1.06 & 4.56 & 225 & .000 \\
\hline CC is clear & private & 115 & 4.03 & 0.96 & & & \\
\cline { 2 - 5 } & state & 112 & 3.46 & 0.82 & 4.77 & 225 & .000 \\
\hline
\end{tabular}




\begin{tabular}{lllllllll}
\hline $\begin{array}{c}\text { Class communi- } \\
\text { cation }(\mathrm{CC})\end{array}$ & Type of college & $\mathbf{N}$ & $\mathbf{M}$ & $\mathrm{SD}$ & $\mathbf{t}$ & $\mathrm{df}$ & $\mathbf{p}$ \\
\hline CC is brief & private & 115 & 3.4 & 1.01 & & & \\
\cline { 2 - 7 } & state & 112 & 2.91 & 0.99 & 3.67 & 225 & .000 \\
\hline CC is interesting & private & 115 & 4.11 & 0.85 & & & \\
\cline { 2 - 7 } & state & 112 & 3.44 & 1.00 & 5.46 & 225 & .000 \\
\hline
\end{tabular}

Table 2 shows estimates of the characteristics of class communication a statistically significant difference between the students of private and state colleges, where the private college students demonstrate greater presence of the characteristics of class communication $(\mathrm{t}=6.355, \mathrm{df}=225, \mathrm{p}=0.000)$, compared to the state college students. Research results can confirm H3 Private college students report greater presence of the characteristics of teaching communication in comparison with state college students.

\section{Web-based quantitative interviews}

A semi-structured interview conducted online in 2014 researched the students' general $(\mathrm{N}=40)$ satisfaction with communication in university teaching. The results show greater satisfaction of the private college students $(90 \%, \mathrm{~N}=18)$ compared to the state college students $(75 \%, \mathrm{~N}=15)$. The second part of the interview referred to proposals related to communication in university teaching. The answers were categorized and presented in Table 3.

Table 3. Suggestions for improvement of communication at university level

\begin{tabular}{|c|c|c|c|c|}
\hline & Private colleges & $f / \%$ & State colleges & $\mathrm{f} / \%$ \\
\hline $\begin{array}{l}\text { Extracur- } \\
\text { ricular } \\
\text { communi- } \\
\text { cation }\end{array}$ & $\begin{array}{l}\text { using contemporary } \\
\text { technologies } \\
\text { more incentive when } \\
\text { discussing certain topics on } \\
\text { forums }\end{array}$ & $\begin{array}{l}14 / 70 \\
12 / 60\end{array}$ & $\begin{array}{l}\text { - using contemporary } \\
\text { technologies } \\
\text { - quicker response (via } \\
\text { e-mail or Moodle) } \\
\text { - more "face to face“ } \\
\text { communication }\end{array}$ & $\begin{array}{l}18 / 90 \\
14 / 70 \\
12 / 60 \\
\end{array}$ \\
\hline $\begin{array}{l}\text { Class com- } \\
\text { munication }\end{array}$ & $\begin{array}{l}\text { - asking more questions in } \\
\text { class by students } \\
\text { - more mutual active listening } \\
\text { (by both teachers and } \\
\text { students) }\end{array}$ & $\begin{array}{l}12 / 60 \\
5 / 25\end{array}$ & $\begin{array}{l}\text { - greater motivation by } \\
\text { teachers } \\
\text { - using various social types } \\
\text { would enable different } \\
\text { types of communication } \\
\text { (group, pair, circle) }\end{array}$ & $\begin{array}{l}13 / 65 \\
12 / 60\end{array}$ \\
\hline
\end{tabular}


Talking about extracurricular communication, Table 3 shows that the students of both colleges ( $90 \%$ state, $80 \%$ private) are happy to communicate with teachers using modern technology to a much greater extent than they have been doing. The private college students increasingly use social networks to communicate with each other but they find that there are still not enough course-related topics (60\%) to address greater problems. However, the state college students greatly value time response (70\%). The state college students miss "face to face" communication $(60 \%)$ and believe that consultations once a week are not enough to personally talk with teachers.

Observing class communication we can say that in this area the students of the state and private universities emphasize different things. The private school students miss being asked more questions (60\%) that would inspire discussion and interest. Also in this section they emphasize the importance of experience (by teachers/other scientists who are essential to their profession) that can help resolve posed problems. In addition, the private college students lack more active listening $(25 \%)$ by the professors, but also by their fellow students because that shows evident respect for different opinions, but also for encouraging communication in general.

The state college students consider teaching of communication still insufficiently stimulated by professors (65\%). A few students (30\%) believe that teachers set rather rhetorical questions and do not expect a response. That should certainly change and enrich the teaching quality and successful communication, and this is the students' feedback that can contribute to the issue of communication. It is particularly important that the students stress the importance of exchange of social forms (60\%) in teaching, because social forms contribute to different types of communication.

\section{Discussion}

Research results show that the private college students are, on average, more satisfied with class communication than the state college students. In the private colleges, the representation of the communicative competence is $20 \%$ higher than that in the state colleges. In addition, the private college students are more satisfied with communication efficiency, accessibility of professors and speed of response. We can say that the teachers and students at the private colleges are more inclined to informal consultations, which create a relaxed and friendly atmosphere. Also, satisfaction with communication refers to communication quality, teachers' 
abilities to recognize nonverbal messages resulting in the creation of a positive environment in the classroom. Data that is not in favor of the state universities is alarming and a sign that something should change. Certainly, it is necessary to start with oneself and educate oneself in the field of communication so that our messages would be clear, motivating and unambiguous. In addition, it is important to get students used to the necessity of class communication, thus contributing to teaching quality.

There is a statistically significant difference between the students of private and state universities, where the students of private universities demonstrate greater presence of the characteristics of teaching communication (simplicity, clarity, brevity and interest) compared to the students of the state universities. Mentioning the frequency of communication before and after the teaching process, the students of private universities communicate with teachers more frequently than the students of the state universities. The fact that we cannot forget is that private university teachers and students usually work in small groups, in which communication itself is more successful and better, but research poses new questions concerning the recognition of other factors according to which students of private schools evaluate teachers as communication competent.

Answers obtained with the use of the interviews conducted helped us to objectively approach the previously received answers to the questionnaire and analysis of documentation. In extracurricular communication, the students want greater use of modern technologies, quicker response to queries, encouragement in debate, greater motivation by all participants of the educational process, active listening, and change of social forms in the development of different communication types. Changing activities in the classroom as well as social forms are a combination for successful and efficient communication.

\section{Conclusions}

Since communication is the basis of the teaching process, the underlying study problem was to determine possible differences in expressing satisfaction with communication. The aim was to examine the students' attitudes towards and opinions on private and state university characteristics, methods, frequency, quality and communication in the learning process, and the student-teacher relationship.

The research scientific value is evident in the selection of the research problem, original instruments, collected empirical data and theoretical explanation of the importance of changes in teaching communication. In addition to the presentation 
of the students' attitudes and finding ideas for improving teaching communication, the study points to the importance of new changes affecting teaching communication. Methodologically, this research represents a genuine attempt to move away from the positivist approach.

For further research, the authors suggest exploring the communicative competence of university professors representing the imperative competence of local and foreign universities, which are also indicators of quality in university teaching.

\section{References}

Bognar, L., Dubovicki, S. (2012). Emotions in the Teaching Process. Croatian Journal of Education, 14 (1), 135-163

Bratanić, M. (2002). Paradoks odgoja. Zagreb: Hrvatska sveučilišna naknada.

Čaldarović, O., Šarinić, J. (2008). Suvremena komunikacijska tehnologija i urbana sredina prostor, mjesta, vrijeme. Socijalna ekologija, 17 (4), 331-341

Čudina-Obradović, M., Težak, D. (1995). Mirotvorni razred. Zagreb: Znamen.

Dubovicki, S., Banjari, I. (2014). Students' attitudes on the quality of university teaching. Sodobna pedagogika, 65/131, 2, 42-58

Duff, A.S. (2003). Higher education teaching. A communication perspective active learning in higher education. London, Thousand Oaks, CA and New Delhi: The Institute for Learning and Teaching in Higher Education and SAGE Publications, 4(3), 256-270

Fojtik, R. (2014). Mobile Technologies Education. Procedia - Social and Behavioral Sciences, $143,342-346$

Katz, L.G., McClellan, D.E. (1999). Poticanje razvoja dječje socijalne kompetencije: uloga odgajateljica i učiteljica. Zagreb: Educa.

Pirani, J.A., \& Sheehan, M.C. (2009). Spreading the Word: Messaging and communications in higher education (Research Study, Vol. 2). Boulder, CO: EDUCAUSE Center for Applied Research. Retrieved 10/09/2015, from https://net.educause.edu/ir/library/pdf/EKF/ EKF0902.pdf

Salloum, Sara R. (2011). Student Perceptions of Computer-Mediated Communication Tools in online learning: Helpfulness and Effects on Teaching, Social, and Cognitive Presence, doctoral dissertation. ProQuest LLC.

Sekulić-Majurec, A. (2007). Uloga sudionika odgojno-obrazovnog procesa u stvaranju, provedbi i vrednjovanju kurikuluma, u: (Ur. Previšić, V.) Kurikulum: teorije, metodologija, sadržaj, struktura. Zagreb: Školska knjiga, 351-383.

Shannon, C.E. (1948). A Mathematical Theory of Communication. Bell System Technical Journal 27(3): 379-423.

Vaughan, N. \& Lawrence, K. (2013). Investigating the role of mobile devices in a blended pre-service teacher education program. Canadian Journal of Higher Education 43(3), 56-77

Wrench, S.J., Richmond, P.V., Goriian, J. (2009). Communication, Affect, \& Learning in the Classroom. San Francisco, California: Creative Commons. 